\title{
A protoconnectionist theory of memory
}

\author{
GREGORY V. JONES \\ University of Warwick, Coventry, England
}

\begin{abstract}
I. A. Richards published a chapter entitled "Memory" in 1924 in which he proposed what may be viewed as the outline of a connectionist theory of memory. However, this protoconnectionist theory attracted no subsequent attention. There appear to be two types of reason for this neglect. The first concerns the impossibility at that time of implementing the theory in the form of an explicit model. The second concerns the nature of Richards's career. On the one hand, Richards did not himself subsequently develop his theory of memory any further. On the other, the fact that Richards was not generally perceived as a psychologist probably impeded the dissemination of his theory among psychologists. The neglect of Richards's theory demonstrates the range of factors, other than the strictly scientific, which can be important in determining the influence or otherwise of a psychological theory.
\end{abstract}

A number of histories of connectionism have recently been published (e.g., Valentine, 1989; Walker, 1990). These generally trace the direct antecedents of connectionism back to developments during the 1940s (Hebb, 1949; McCulloch \& Pitts, 1943). However, an earlier theory of memory appears to have been overlooked. Consider

a solid with a large number of facets upon any one of which it can rest. If we try to balance it upon one of its coigns or ridges it settles down upon the nearest facet. In the case of the neural system we are trying to suggest each stable poise has been determined by a definite set, or better, context of conditions. Membership of this context is what corresponds to nearness to a facet. The partial return of the context causes the system to behave as though conditions were present which are not, and this is what is essential in memory.

One might at first sight take the preceding passage to be describing a connectionist model formulated within the last decade. Compare, for example, the description by Quinlan (1991, pp. 204-205) of the attractor network model of Hinton and Shallice (1989, 1991):

Each word was paired with a semantic pattern generated from the available 68 semantic primitives. . . . A given semantic vector corresponded to a fixed point in this 68dimensional space. Such points were rather frighteningly referred to as vertices of a 68 -dimensional hypercube. The shifting terminology, however, also refers to them as "point attractors" lying at the bottom of "basins of attraction." ... The implication here is that vectors that only partially map onto a familiar vector will correspond to a point within a particular basin of attraction.

The first passage was in fact, however, written by I. A. Richards (1924, p. 105) approximately 70 years ago. The theory of memory proposed by Richards has a remarkably modern appearance. It was expounded in a chapter

Correspondence should be addressed to G. V. Jones, Department of Psychology, University of Warwick, Coventry CV4 7AL, England. explicitly termed "Memory," forming part of a celebrated monograph that was to remain in print up to the present day. Why, then, has Richards's theory of memory been completely ignored, as far as I have been able to discover, throughout these 70 years? The answer lies partly in the nature of the theory itself, and partly in the nature of Richards's work. These will be briefly considered in turn.

\section{Richards's Theory of Memory}

The theory forms the subject of chapter 14 of Richards (1924). ${ }^{1}$ Richards's starting point was dissatisfaction not only with the idea of memory stores but also with the idea of memory pathways:

The old theory of a kind of Somerset House ${ }^{2}$ of past impressions has given place to an account in terms of facilitations of neural paths, lowered resistances in synapses, and so forth. It was natural that as the broad lines of neural activity came to be known, psychologists should attempt to make use of them. But on close examination it is clear that their interpretations were far too crude. Fixed "paths," one for every item of experience which has ever taken place, and others for every kind of connection into which the items come, however multitudinous we make them, no longer explain what can be observed in behaviour and experience. (pp. 103-104; footnote added)

Richards (1924) cited Von Kries and Koffka ${ }^{3}$ as previously arguing that recognition can occur even when different pathways must be involved. However, he rejected the multiple-trace theory of Semon ${ }^{4}$ on the grounds that "mere multiplication of the entities" (p. 104) did not produce a satisfactory explanation. Instead, he proposed the following:

Imagine an energy system of prodigious complexity and extreme delicacy of organisation which has an indefinitely large number of stable poises. Imagine it thrown from one poise to another with great facility, each poise being the resultant of all the energies of the system. Suppose now that the partial return of a situation which has formerly caused it to assume a stable poise, throws it into an unsta- 
ble condition from which it most easily returns to equilibrium by reassuming the former poise. Such a system would exhibit the phenomena of memory; but it would keep no records though appearing to do so. (p. 104)

Richards (1924) went on to give a concrete example of such a scheme, in terms of the multidimensional structure cited earlier. He concludes that in comparison with

the Archival and Pathway Theories ... it does avoid the chief deficiencies of those theories, it does suggest why only some conjunctions of experiences become "associated," those namely which yield a stable poise. And it suggests why a thing should be recognised as the same though appearing in countless different aspects; every time it appears different conditions occur which, none the less, lead to one and the same stable poise, as the polyhedron we imagined may settle down on one and ${ }^{5}$ the same facet from all the surrounding ridges. (p. 105; footnote added)

Richards's theory can be seen to have most of the hallmarks (nonsymbolic representation, distributed storage, redintegrative processing, neural plausibility) of the connectionist models that have in recent years been acclaimed as constituting a possible paradigm shift within psychology (see, e.g., McClelland, 1988; Schneider, 1987; Smolensky, 1988). However, to the extent that modern connectionist models resemble the theory of Richards (1924), they do so because their principles have been independently rediscovered rather than inherited from Richards. Why, then, did his theory fail to influence subsequent theories of memory?

Part of the reason for the neglect of Richards's theory is undoubtedly that Richards was ahead of his time. Since electronic computers had not been invented, it was not possible for his theory to be implemented in the kind of working simulation that is now so persuasive. This also meant that his theory did not deliver the kind of readily testable prediction that would have been attractive to experimental psychologists. However, another part of the reason probably lies in other aspects of Richards's work.

\section{Richards's Work}

Ivor Armstrong Richards was born in 1893 in Cheshire, England, and died in Cambridge, England, in 1979. Since his death, a substantial biography has been published (Russo, 1989), together with a selection of his letters (Constable, 1990). ${ }^{6}$

Richards's academic career was spent mainly in the two Cambridges. He went up to Magdalene College, Cambridge (England), in 1911 and was elected a Fellow there in 1926. He moved to Cambridge (Massachusetts) in 1939 and was appointed one of Harvard's five University Professors in 1943. Finally, he returned to Magdalene College in 1974 (Russo, 1989, pp. 15, 94, 432, 437, and 666).

Richards's work was consistently concerned with language. However, the nature of the problems that he addressed changed. In his earlier work, he was concerned with the theoretical analysis of language and literature. In later work, from the 1930 s, the emphasis changed to the role of language and literacy in education. As Richards himself said, "I decided to back out of literature, as a subject, completely, and go into elementary education" (Brower, 1973, p. 29). This was a surprising decision, since Richards is widely recognized as the creator of the modern study of literature. For example, Bradbrook (1973) observed that "Principles of Literary Criticism introduced the collaborative yet self-critical examination of English literature which justified it as a discipline" (p. 66). Similarly, Lord Annan (1990) observed that "the close reading of the text Richards demanded he called Practical Criticism, better known in America as the New Criticism" (p. 421), and he demonstrated the contribution of this to the general history of ideas.

The circumstances of Richards's career were perhaps responsible for impeding the dissemination of his theory of memory in two ways. First, they may have contributed to the failure by him or his colleagues to develop or even to discuss the model after its 1924 enunciation. Second, the perception of Richards as literary critic rather than as psychologist may have contributed to the failure of the theory to enter the mainstream of psychological thought.

Absence of development of Richards's theory. Richards himself appears never to have developed his theory of memory further. This was perhaps because he was so successfully engaged with projects in other areas. Major works he undertook at about the time he formulated the theory included those of Ogden, Richards, and Wood (1922), Ogden and Richards (1923), and Richards (1929). It is perhaps more surprising that Richards's theory of memory was not discussed in an explicitly psychological work by Ogden (1926). Discussion might have been expected, since much of this book was in fact written by Richards (see Russo, 1989, pp. 89 and 708). Later work on metaphor (Richards, 1936) has been cited by psychologists (see Ortony, 1979), but again did not discuss Richards's theory of memory.

The failure of Richards to develop his theory of memory further was not made good by his colleagues. This perhaps reflects the fact that Richards did not in general attempt to develop his work by acquiring followers. As observed by Bradbrook (1973), "He acquired friends but not disciples. He did not assume the stance of authority, although at times his voice acquired the ring of prophecy or proclamation" (p. 67). Bradbrook's attribution of prophecy to Richards seems particularly appropriate in the case of his theory of memory.

Apart from Richards and his own colleagues, it might have been expected that his theory of memory would have been discussed by those working within psychology proper. However, uncertainty over Richards's status as psychologist perhaps led to neglect of his work by other psychologists.

Richards's status as psychologist. Richards has generally been viewed as a literary critic rather than as a psychologist. The book in which his theory of memory appeared is almost universally categorized as part of the canon of literary criticism rather than psychology. In fact, however, Richards could well be claimed jointly by psy- 
chology. The book has a strongly psychological perspective, with the preface (Richards, 1924, p. 2; p. 3 in later editions) referring justly to its attempt "to link even the commonplaces of criticism to a systematic exposition of psychology." Richards's involvement with psychology dated back to his having studied psychology as part of the Moral Sciences Tripos at Cambridge. In a Festschrift interview with Reuben Brower (1973), Richards described the origins of the work in question as follows:

R.B.: How did you turn from that intense interest in meaning to the Principles?

I.A.R.: What mattered was that I was interested in psychology, a rather old-fashioned psychology: prebehavioristic, although I did know a good deal about behavioris $\mathrm{m}^{7}$ and did something towards joining them up. But my psychology came out of G. F. Stout, out of the big James Ward article in the Encyclopedia Britannica, and William James's two volumes, The Principles of Psychology. Those were the real formative things. Those and Sherrington's Integrative Action of the Nervous System to put the physiology in it. ${ }^{8}$ I was someone really saturated in psychology and neurology. (p. 28; footnotes added)

The fact that Richards's professional affiliation was nevertheless outside psychology perhaps explains why his fellow student of memory at Cambridge, Frederic Bartlett, did not mention Richards either in his influential $R e$ membering (1932), or in his historical accounts of psychology at Cambridge (Bartlett, 1936, 1937). It is interesting, nevertheless, to note that Russo (1989, p. 37) gives the minutes by Bartlett and Bertrand Russell of a psychological paper presented by Richards in 1915 to the Moral Sciences Club at Cambridge.

Only one psychologist, B. F. Skinner, contributed to Richards's Festschrift, and his contribution (Skinner, 1973) focused primarily on work of his own rather than Richards's work. More widely, Richards does not appear to figure in any history of psychology, with one exception. Hearnshaw (1964) described Richards's work as "important, stimulating, and at the same time essentially forward-looking" (p. 229). As with Bradbrook (1973), Hearnshaw's attribution of prophetic or forward-looking qualities to Richards can be seen to be well borne out in the case of Richards's theory of memory.

\section{REFERENCES}

Annan, N. (1990). Our age. London: Weidenfeld \& Nicolson.

Bartlett, F. C. (1932). Remembering: A study in experimental and social psychology. Cambridge: Cambridge University Press.

Bartlett, F. C. (1936). Frederic Charles Bartlett. In C. Murchison (Ed.), A history of psychology in autobiography (Vol. 3, pp. 39-52). Worcester, MA: Clark University Press.

BartLetT, F. C. (1937). Cambridge, England: 1887-1937. American Journal of Psychology, 50, 97-110.

Braderook, M. C. (1973). I. A. Richards at Cambridge. In R. Brower, H. Vendler, \& J. Hollander (Eds.), I. A. Richards: Essays in his honor (pp. 61-72). New York: Oxford University Press.

Brower, R. (1973). Beginnings and transitions: I. A. Richards interviewed by Reuben Brower. In R. Brower, H. Vendler, \& J. Hollander
(Eds.), I. A. Richards: Essays in his honor (pp. 15-41). New York: Oxford University Press.

Constable, J. (Ed.) (1990). Selected letters of I. A. Richards, CH. Oxford: Oxford University Press/Clarendon Press.

HEARNSHAW, L. S. (1964). A shon history of British psychology 18401940. London: Methuen.

HEBA, D. O. (1949). The organization of behavior: A neuropsychological theory. New York: Wiley.

Hinton, G. E.. \& Shallice, T. (1989). Lesioning a connecrionist network: Investigations of acquired dyslexia. (Tech. Rep. CRG-TR-893). Toronto: University of Toronto, Department of Computer Science. Hinton, G. E., \& Shaluce, T. (1991). Lesioning an attractor network: Investigations of acquired dyslexia. Psychological Review, 98. 74-95.

James, W. (1890). Principles of psychology (Vols. 1-2). New York: Henry Holt; London: Macmillan.

KOFFKA, K. (1923). The growth of the mind: An introduction to childpsychology (R. M. Ogden, Trans.). London: Kegan Paul, Trench, Trubner. (Original work published 1921)

MCCLELLAND, J. L. (1988). Connectionist models and psychological evidence. Journal of Memory \& Language, 27, 107-123.

MсCulloch, W. S., \& PITts, W. H. (1943). A logical calculus of the ideas immanent in nervous activity. Bulletin of Mathematical Biophysics, 5, 115-133.

OGDEN, C. K. (1926). The meaning of psychology. New York: Harper $\&$ Brothers.

OGDEN, C. K., \& Richards, I. A. (1923). The meaning of meaning: A study of the influence of language upon thought and of the science of symbolism. London: Kegan Paul, Trench, Trubner.

OGDEN, C. K., RICHARDS, I. A., WOOD, J. (1922). The foundations of aesthetics. London: George Allen \& Unwin.

Ortony, A. (Ed.) (1979). Metaphor and thought. Cambridge: Cambridge University Press.

Quinlan, P. (1991). Connectionism and psychology: A psychological perspective on new connectionist research. New York: Harvester Wheatsheaf.

RiCha RDS, I. A. (1924). Principles of literary criticism. London: Kegan Paul, Trench, Trubner; New York: Harcourt Brace.

Richards, I. A. (1926). Review of Behaviorism by J. B. Watson. Criterion, 4, 372-378.

Richards, I. A. (1929). Practical criticism: A study of literary judgment. London: Kegan Paul, Trench, Trubner.

Richards, I. A. (1936). The philosophy of rhetoric. New York: Oxford University Press.

Russo, J. P. (1989). I. A. Richards: His life and work. Baltimore, MD: Johns Hopkins University Press; London: Routledge.

SCHACTER, D. L. (1982). Stranger behind the engram: Theories of memory and the psychology of science. Hillsdale, $\mathrm{NJ}$ : Erlbaum.

Schacter, D. L., Eich, J. E., Tulving, E. (1978). Richard Semon's theory of memory. Journal of Verbal Learning \& Verbal Behavior. 17, $721-743$.

SCHNeIder, W. (1987). Connectionism: Is it a paradigm shift for psychology? Behavior Research Methods, Instruments, \& Computers, 19. 73-83.

Semon, R. (1921). The mneme (L. Simon, Trans.). London: George Allen \& Unwin. (Original work published 1904)

SEMON, R. (1923). Mnemic psychology (B. Duffy, Trans.). London: George Allen \& Unwin, 1923. (Original work published 1909)

SHERRINGTON, C. S. (1906). The integrative action of the nervous system. New York: Scribner.

SKINNER, B. F. (1973). Reflections on meaning and structure. In R. Brower, H. Vendler, \& J. Hollander (Eds.), I. A. Richards: Essays in his honor (pp. 199-209). New York: Oxford University Press.

SMOLENSKY, P. (1988). On the proper treatment of connectionism. Behavioral \& Brain Sciences, 11, 1-74.

Stout, G. F. (1896). Analytic psychology (Vols. 1-2). London: Swan Sonnenschein.

VAlentine, E. R. (1989). Neural nets: From Hartley and Hebb to Hinton. Journal of Mathematical Psychology, 33, 348-357.

VON KRIES, J. (1901). Über die materiellen Grundlagen der 
Bewusstseins-Erscheinungen [On the material basis of the phenomena of consciousness]. Tübingen: Mohr.

WALKER, S. F. (1990). A brief history of connectionism and its psychological implications. AI \& Society, 4, 17-38.

WARD, J. (1918). Psychological principles. Cambridge: Cambridge University Press.

\section{NOTES}

1. Although the book was published in 1924 , Russo $(1989$, p. 727$)$ notes that copies of the first edition are generally undated or carry the date 1925.

2. Somerset House is the building in London where, until 1974, births, marriages, and deaths were registered by the Registrar General.

3. Richards was doubtless referring to Von Kries (1901) and Koffka (1921/1923).

4. Richards was doubtless referring to Semon (1904/1921, 1909/1923). See also Schacter, Eich, and Tulving (1978) and Schacter (1982); for
Semon's multiple-trace theory, see especially Schacter et al. (1978, pp. 734-737).

5. The first edition has here the word "at" instead, corrected to "and" (as shown) in later editions.

6. The letters "CH" appearing after Richards's name in the title of this book derive from Richards's having been made a Companion of Honour (a British order of chivalry, limited to 65 members) in 1964 (see Constable, 1990, p. xxxiv).

7. See Richards (1926)

8. G. F. Stout had earlier been Lecturer in Moral Sciences at Cambridge; his works (e.g., Stout, 1896) went through many editions. James Ward was Professor of Mental Philosophy at Cambridge; his Encyclopedia Britannica article formed the basis of Ward (1918). Other works referred to are James (1890) and Sherrington (1906).

(Manuscript received July 20, 1992; revision accepted for publication September 30, 1992.) 